\title{
Faktor-Faktor yang Berhubungan dengan Kunjungan Balita Ke Posyandu di Wilayah Kerja Puskesmas Anak Air Kota Padang Tahun 2017
}

\author{
Faridah BD ${ }^{1}$, Yussie Ater Merry ${ }^{2}$, Tessy Andriani ${ }^{3}$ \\ ${ }^{1}$ Politeknik Kesehatan Kemenkes Padang \\ email :faridahbd140@gmail.com \\ 2 Politeknik Kesehatan Kemenkes Padang \\ email:yussi@gmail.com \\ ${ }^{3}$ Politeknik Kesehatan Kemenkes Padang \\ email : tessykamil@yahoo.co.id
}

\begin{abstract}
ABSTRAK
Sebagai tolak ukur peran serta masyarakat untuk memanfaatkan posyandu dilihat dari cakupan ditimbang dibagi jumlah sasaran (D/S), di Sumatera Barat tahun 2015 mencapai 71,99\%, sedangkan di Kota Padang pada tahun mencapai 69,6\% cakupan D/S terendah Puskesmas Anak Air yaitu tahun $2014(41,2 \%), 2015(66,36 \%)$ dan 2016 (44,2\%). Dari data tersebut terlihat bahwa pencapaian ini sangat jauh dari target nasional yaitu $85 \%$. Untuk itu peneliti melakukan penelitian tentang faktor-faktor yang berhubungan dengan kunjungan balita ke posyandu.

Jenis penelitian adalah kuantitatif dengan rancangan cross sectional. Penelitian di Wilayah Kerja Puskesmas Anak Air Padang pada tanggal 6 - 12 Juni 2017, populasi sebanyak 2944 orang, sampel sebanyak 97 orang diambil dengan teknik cluster sampling. Data dikumpulkan dengan cara membagikan kuesioner. Analisis univariat menggunakan distribusi frekuensi dan analisis bivariat menggunakan uji chi square.

Hasil penelitian didapatkan 52,6\% kunjungan ke posyandu kurang, 54,6\% responden berpengetahuan rendah, 53,6\% tidak bekerja, 56,7\% memiliki peran kader yang kurang baik. Terdapat hubungan yang bermakna antara tingkat pengetahuan $(\mathrm{p}=0,000)$, pekerjaan $(\mathrm{p}=0,000)$ dan peran kader $(p=0,000)$ dengan kunjungan ibu balita.

Dapat disimpulkan bahwa ada hubungan tingkat pengetahuan, pekerjaan dan peran kader dengan kunjungan ibu balita ke Posyandu. Untuk itu diharapkan bagi pengelola program posyandu di Puskesmas senantiasa melaksanakan penyuluhan ke masyarakat khususnya pada ibu bekerja sehingga kunjungan ibu balita ke posyandu semakin meningkat. Diharapkan bagi peneliti selanjutnya agar dapat melanjutkan penelitian ini dengan melihat faktor-faktor lain yang berhubungan dengan kunjungan ibu balita ke posyandu.
\end{abstract}

\section{Kepustakaan : 18 (2004 - 2016)}

Kata Kunci : pengetahuan, pekerjaan, peran kader, kunjungan posyadu

\section{ABSTRACT}

As a measure of community participation to take advantage of posyandu coverage of $D / S$, the national target is 85\%, in West Sumatera 2015 reaches $71.99 \%$, while in Padang city reaches 69.6\% year. Of the 22 Puskesmas in Padang were found the lowest D/S coverage of Ulak Karang Clinic (41,2\%). From the data it is seen that this achievement is very far from the national target of $85 \%$. For that researcher do research about factors related to visit mother of toddler to posyandu. The research type is quantitative with cross sectional design. The study was conducted in the Working Area of Puskesmas Anak Air Padang on 6 - 12 June 2017, a population of 2944 people, a sample of 97 people. Cluster sampling sampling technique. Data were collected by angket. Univariate analysis using frequency distribution and bivariate analysis using chi square test. The result of the research is 52,6\% of visit to posyandu less, 54,6\% low knowledge respondent, 53,6\% not working, 56,7\% have role of less good cadre. There is a significant relationship between the level of knowledge $(p=0,000)$, occupation $(p=0,000)$ and the role of cadres $(p=0,000)$ with the visit of the infant mother to the Posyandu. The result of this research can be concluded that there is correlation of knowledge level, occupation and role of cadre with visit mother of balita to Posyandu. Therefore, it is expected that the posyandu program managers in Puskesmas always 
carry out counseling to the community especially on working mothers so that the visit of mother toddler to posyandu is increasing. It is hoped for further researchers to continue this research by looking at other factors related to the visit of the mother toddler to the posyandu.

Keywords : Knowledge, work, role of cadres, visit posyandu

\section{PENDAHULUAN}

Puskesmas adalah fasilitas pelayanan kesehatan yang menyelenggarakan upaya kesehatan masyarakat dan upaya kesehatan perorangan tingkat pertama, dengan lebih mengutamakan upaya promotif dan pereventif, untuk mencapai derajat kesehatan masyarakat yang setinggi-tingginya di wilayah kerjanya. Mendukung upaya kesehatan yaitu dengan cara meningkatkan peran serta masyarakat salah satu wujudnya

adalah posyandu. Posyandu sebagai perwujudan dari peran serta masyarakat tidak serta merta hadir dan bergerak dengan sendirinya, dukungan pemerintah terhadap keberadaan dan kesinambungan posyandu terus diupayakan. Bermacam kegiatan dan program telah dilaksanakan agar posyandu tetap eksis dan menjadi gerbang depan pemberdayaan masyarakat serta dapat menjadi salah satu indikator keberhasilan kegiatan posyandu adalah meningkatnya status gizi anak sehingga jumlah anak yang berat badannya tidak naik semakin menurun. ${ }^{1}$

Kegiatan posyandu tersebut tidak terlepas dari masalah yang berasal dari dalam maupun dari luar posyandu. Masalah dari dalam yang dihadapi oleh posyandu adalah bagaimana mencapai target peningkatan status gizi balita. Selain itu masalah sarana dan prasarana juga menjadi masalah internal. Sedangkan masalah eksternal posyandu adalah kurangnya dukungan dari berbagai kebijakan pemerintah dalam menopang keberlangsungan posyandu dan kurangnya partisipasi aktif dari masyarakat dalam mengembangkan posyandu. Dimana

posyandu menjadi efektif dalam meningkatkan derajat kesehatan balita khususnya dan masyarakat pada umumnya

dikarenakan adanya dukungan dari masyarakat setempat serta keterampilan kader dalam menjalankan tugasnya dan dalam menjalankan program-program posyandu yang tentunya sudah disesuaikan dengan kondisi lingkungan setempat. $^{2}$
Posyandu bermanfaat bagi masyarakat, Kader, pengurus Posyandu dan tokoh masyarakat serta bagi puskesmas. Manfaat bagi masyarakat antara lain memperoleh kemudahan untuk mendapatkan informasi dan pelayanan kesehatan dasar, terutama berkaitan dengan penurunan AKI dan AKB, memperoleh bantuan secara profesional dalam pemecahan masalah kesehatan terutama terkait kesehatan ibu dan anak serta efisiensi dalam mendapatkan pelayanan terpadu kesehatan dan sektor lain

terkait. Manfaat bagi kader, pengurus Posyandu dan tokoh masyarakat antara lain untuk mendapatkan informasi terdahulu tentang upaya kesehatan yang terkait dengan penurunan AKI dan AKB, mewujudkan aktualisasi dirinya dalam membantu masyarakat menyelesaikan masalah kesehatan terkait dengan penurunan AKI dan AKB. Sedangkan bagi puskesmas antara lain optimalisasi fungsi puskesmas sebagai pusat

penggerak pembangunan berwawasan kesehatan, pusat pemberdayaan masyarakat, pusat pelayanan kesehatan strata pertama, lebih spesifik membantu masyarakat dalam pemecahan masalah kesehatan sesuai kondisi setempat. $^{2}$

Dalam operasionalnya, kegiatan posyandu dilakukan 1 kali setiap bulan yang

diselenggarakan oleh kader bersama masyarakat. Indikator yang digunakan adalah jumlah balita yang ditimbang dibagi dengan jumlah balita seluruhnya (D/S), sebagai tolak ukur peran serta masyarakat untuk memanfaatkan posyandu Data Propinsi Sumatera Barat pada tahun 2015 cakupan penimbangan balita yaitu yang ditimbang dibagi jumlah sasaran (D/S) mencapai 71,99\% dengan target $85 \%$, untuk cakupan balita yang mengalami kenaikan berat badan dibagi jumlah sasaran (N/D) yaitu pada balita mencapai 77,56\%. Propinsi Sumatera Barat menargetkan cakupan penimbangan balita di posyandu mencapai $90 \%$. Sedangkan pada tahun 2016 cakupan D/S sedikit menurun yaitu sebesar $70,6 \% 9$

Sedangkan di Kota Padang dari tahun 2014 - 2016 pemanfaatan kegiatan posyandu dapat 
dilihat dari data kunjungan balita ke posyandu seperti terlihat pada tabel berikut ini

\section{Tabel 1.1}

Cakupan D/S Dinas Kesehatan Kota Padang Tahun 2014 - 2016

\begin{tabular}{|c|c|c|c|c|}
\hline \multirow{2}{*}{ No. } & \multirow{2}{*}{ Puskesmas } & \multicolumn{3}{|c|}{ D/S (Tahun) } \\
\hline & & 2014 & 2015 & 2016 \\
\hline 1 & Padang Pasir & 57.11 & 53.17 & 61.7 \\
\hline 2 & Ulak Karang & 41.2 & 47.65 & 47.6 \\
\hline 3 & Alai & 73.87 & 55.86 & 55.9 \\
\hline 4 & Air Tawar & 58.03 & 77.13 & 75.7 \\
\hline 5 & Pemancungan & 65.03 & 71.96 & 80.9 \\
\hline 6 & Rawang & 67.33 & 66.18 & 68.9 \\
\hline 7 & Seberang Padang & 52.48 & 53.82 & 56.5 \\
\hline 8 & Andalas & 71.67 & 59.55 & 69.6 \\
\hline 9 & Nanggalo & 81.54 & 51.79 & 66.5 \\
\hline 10 & Lapai & 59.1 & 75.02 & 68.1 \\
\hline 11 & Pengambiran & 68.15 & 45.33 & 62.9 \\
\hline 12 & Lubuk Begalung & 64.57 & 75.14 & 81.5 \\
\hline 13 & Lubuk Buaya & 77.73 & 77.62 & 71.1 \\
\hline 14 & Air Dingin & 58.8 & 62.75 & 60.7 \\
\hline 15 & Anak Air & 76.57 & 66.36 & 44.2 \\
\hline 16 & Ikur Koto & 75.96 & 77.2 & 70.1 \\
\hline 17 & Bungus & 70.17 & 68.67 & 80.2 \\
\hline 18 & Pauh & 84.53 & 78.43 & 79.4 \\
\hline 19 & Kuranji & 58.15 & 71.33 & $\begin{array}{c}69.0 \\
8 \\
\end{array}$ \\
\hline 20 & Ambacang & 76.28 & 91.64 & 92.1 \\
\hline 21 & Belimbing & 71.45 & 44.31 & 64.8 \\
\hline 22 & Lubuk Kilangan & 79.87 & 61.74 & 69.6 \\
\hline
\end{tabular}

Sumber : Profil Dinkes Kota Padang

Berdasarkan tabel diatas dapat dilihat bahwa cakupan D/S Kota Padang tahun 2014 yang terendah terdapat di Puskesmas Ulak Karang (41,2\%), tahun 2015 yang terendah terdapat di Puskesmas Belimbing $(44,31 \%)$ dan pada tahun 2016 yang terendah terdapat di Puskesmas Anak Air (44,2\%). Dari data tersebut terlihat bahwa pencapaian ini sangat jauh dari target nasional yaitu $85 \%$.

Tingkat partisipasi masyarakat dalam kegiatan posyandu hasilnya minimal harus capai $85 \%$ apabila di bawah $85 \%$ maka dikatakan partisipasi mayarakat untuk kegiatan pemantauan pertumbuhan dan perkembangan berat badan sangatlah rendah. Hal ini akan berakibat pada balita tidak akan terpantau oleh petugas kesehatan ataupun kader posyandu dan memungkinkan balita ini tidak diketahui pertumbuhan berat badannya atau pola pertumbuhan berat badannya. ${ }^{11}$

Cakupan penimbangan balita $(\mathrm{D} / \mathrm{S})$ sangat penting karena merupakan indikator yang berkaitan dengan cakupan pelayanan gizi balita, cakupan pelayanan dasar khususnya imunisasi dan prevalensi gizi kurang. Semakin tinggi cakupan $\mathrm{D} / \mathrm{S}$, semakin tinggi cakupan vitamin A dan semakin tinggi cakupan imunisasi.

Banyak faktor yang mempengaruhi kunjungan ibu balita ke posyandu. Menurut Lawrence Green, perilaku kesehatan

dipengaruhi oleh faktor predisposisi (pengetahuan, sikap, nilai-nilai budaya, umur, pendidikan dan pekerjaan), faktor pendukung (ketersediaan sumber daya dan fasilitas kesehatan), dan faktor pendorong (dukungan keluarga, peran kader kesehatan dan perilaku tokoh masyarakat). Kunjungan ibu balita ke posyandu berkaitan dengan perilaku kesehatan, perilaku kesehatan hakikatnya adalah hal-hal yang berkaitan dengan tindakan atau kegiatan ibu dalam memelihara dan meningkatkan kesehatan balitanya. Kesehatan seseorang dipengaruhi atau terbentuk dari beberapa karakteristik. Menuruthasil penelitian

Tuti Pradianto tentang faktor-

faktor yang mempengaruhi ketidak hadiran Ibu Balita dan Penggunaan Posyandu di Kecamatan Botumoito tahun 2015, menyatakan bahwa perilaku kunjungan ibu balita di posyandu dapat dipengaruhi oleh beberapa faktor antara lain pendidikan ibu $(\mathrm{p}=$ $0,021)$, umur anak balita $(\mathrm{p}=0,018)$, pekerjaan $\mathrm{ibu}(\mathrm{p}=0,007)$, pengetahuan ibu $(\mathrm{p}=0,036)$, jarak posyandu $(\mathrm{p}=0,041)$, dukungan keluarga $(\mathrm{p}=0,037)$, bimbingan dari petugas kesehatan dan peran kader $(\mathrm{p}=0,004)$.

Faktor berikutnya yang mempengaruhi perilaku adalah pekerjaan. Perilaku ibu membawa balita ke posyandu bagi ibu yang bekerja dan tidak bekerja seharusnya tidak memiliki perbedaan, dikarenakan perilaku tersebut didasari oleh seberapa besar pengetahuan ibu tentang posyandu dan bagaimana mensikapinya. Namun rendahnya jumlah kunjungan balita ke posyandu menunjukkan bahwa ada pengaruh yang disebabkan oleh faktor status ibu bekerja atau tidak. Kepercayaan dan perilaku kesehatan ibu juga hal yang penting, karena penggunaan sarana kesehatan oleh anak berkaiatn erat 
dengan perilaku dan kepercayaan ibu tentang kesehatan dan mempengaruhi keaktifan ke posyandu.

Penelitian lain yang menguatkan dilakukan oleh Pipit Festy Wilianarti, dkk

(2016) tentang faktor-faktor yang mempengaruhi kunjungan ke posyandu di Wilayah Kerja Puskesmas Banjaroya, Kalibawang, Kulon Progo, menemukan bahwa dari hasil penelitian mengenai Determinan factor dapat disimpulkan sebagai berikut: hasil penelitian menunjukkan bahwa, faktor yang mempengaruhi partisipasi ibu dalam kegiatan posyandu di Kejawan Putih Tambak adalah : faktor pengetahuan $(\mathrm{p}=0,026)$, faktor sikap menunjukkan faktor keterjangkauan tempat pelayanan kesehatan $(\mathrm{p}=0,046)$, dan faktor sosial ekonomi $(p=0,043)$.

Berdasarkan hasil survey awal yang peneliti lakukan pada bulan Februari 2017 di Puskesmas Anak Air, dengan melakukan wawancara terhadap 10 orang ibu yang mempunyai balita, didapatkan dari 10 orang ibu 6 orang diantarnya mengatakan sibuk bekerja sehingga tidak dapat datang ke posyandu, 4 orang mengatakan tidak bekerja tetapi tidak mengetahui jadwal posyandu. Dari 10 orang ibu 4 diantaranya mengatakan tidak mengetahui manfaat dan tujuan kegiatan posyandu, 6 orang mengatakan mengerti tujuan diadakan posyandu yaitu menimbang berat badan anak. Dari 10 orang ibu 7 orang mengatakan peran kader posyandu masih kurang karena jarang kader memberitahukan jadwal kegiatan posyandu.

Berdasarkan uraian diatas maka dalam hal ini peneliti merasa tertarik melakukan penelitian tentang

"faktor-faktor yang berhubungan dengan kunjungan balita ke posyandu di Wilayah Kerja Puskesmas Anak Air Kota Padang tahun 2017?"

\section{METODE PENELITIAN}

Jenis penelitian pada penelitian ini adalah survey analitik dengan pendekatan cross sectional study. Penelitian ini telah dilaksanakan di Wilayah Kerja Puskesmas Anak Air Kota Padang. Waktu penelitian dilaksanakan bulan Februari s/d Juni 2017. Pengumpulan data telah dilakukan mulai tanggal 6 - 12 Juni 2017. Populasi dalam penelitian ini adalah semua ibu yang mempunyai anak balita umur 1 - 5 tahun yang ada di Wilayah Kerja Puskesmas Anak Air Kota Padang berjumlah 2944 orang. Teknik pengambilan sampel dalam penelitian

ini adalah cluster sampling yaitu dipergunakan saat unit samplingnya terdiri lebih dari satu elemen populasi (kelompok). Data dikumpulkan dengan cara membagikan kuesioner. Analisis univariat menggunakan distribusi frekuensi dan analisis bivariat menggunakan uji chi square.

\section{HASIL PENELITIAN}

\section{A. Hasil Penelitian}

1. Karakteristik

a. Umur

\begin{tabular}{|l|c|c|c|}
\hline No. & $\begin{array}{c}\text { Kunjungan ke } \\
\text { Posyandu }\end{array}$ & $\mathbf{f}$ & $\boldsymbol{\%}$ \\
\hline 1. & $<20$ tahun & 0 & 0 \\
\hline 2. & $20-35$ tahun & 93 & 95,9 \\
\hline 3. & $>35$ tahun & 4 & 4,1 \\
\hline & Jumlah & 97 & 100,0 \\
\hline
\end{tabular}

Berdasarkan tabel 4.1 dapat dilihat bahwa dari 97 responden sebanyak 93 orang $(95,9 \%)$ berada pada rentang umur $20-35$ tahun.

b. Pendidikan

\begin{tabular}{|l|c|c|c|}
\hline No. & $\begin{array}{c}\text { Kunjungan ke } \\
\text { Posyandu }\end{array}$ & $\mathbf{f}$ & $\boldsymbol{\%}$ \\
\hline 1. & SD & 9 & 9,3 \\
\hline 2. & SMP & 35 & 36,1 \\
\hline 3. & SMA & 51 & 52,6 \\
\hline 4. & PT & 2 & 2,1 \\
\hline & Jumlah & 97 & 100,0 \\
\hline
\end{tabular}

Berdasarkan tabel 4.2 dapat dilihat bahwa dari 97 responden sebanyak 51 orang $(52,6 \%)$ memiliki pendidikan SMA.

\section{Analisis Univariat}

a. Kunjungan Ibu Balita ke Posyandu

\begin{tabular}{|l|c|c|c|}
\hline No. & $\begin{array}{c}\text { Kunjungan ke } \\
\text { Posyandu }\end{array}$ & $\mathbf{f}$ & $\%$ \\
\hline 1. & Kurang & 51 & 52,6 \\
\hline 2. & Baik & 46 & 47,4 \\
\hline & Jumlah & 97 & 100,0 \\
\hline
\end{tabular}


Berdasarkan tabel 4.3 dapat dilihat bahwa dari 97 responden sebanyak 51 orang $(52,6 \%)$ memiliki kunjungan ke posyandu yang kurang.

\section{b. Tingkat Pengetahuan}

\begin{tabular}{|l|c|c|c|}
\hline No. & $\begin{array}{c}\text { Tingkat } \\
\text { Pengetahuan }\end{array}$ & $\mathbf{f}$ & \% \\
\hline 1. & Rendah & 53 & 54,6 \\
\hline 2. & Tinggi & 44 & 45,4 \\
\hline & Jumlah & 97 & 100,0 \\
\hline
\end{tabular}

Berdasarkan tabel 4.4 dapat dilihat bahwa dari 97 responden sebanyak 53 orang $(54,6 \%)$ memiliki tingkat pengetahuan yang rendah tentang posyandu.

\section{c. Pekerjaan}

\begin{tabular}{|l|c|c|c|}
\hline No. & Pekerjaan & f & \% \\
\hline 1. & Bekerja & 45 & 46,4 \\
\hline 2. & Tidak Bekerja & 52 & 53,6 \\
\hline & Jumlah & 97 & 100,0 \\
\hline
\end{tabular}

Berdasarkan tabel 4.5 dapat dilihat bahwa dari 97 responden sebanyak 52 orang $(53,6 \%)$ tidak bekerja.

\section{d. Peran Kader}

\begin{tabular}{|l|c|c|c|}
\hline No. & Peran Kader & f & \% \\
\hline 1. & Kurang Baik & 55 & 56,7 \\
\hline 2. & Baik & 42 & 43,3 \\
\hline & Jumlah & 97 & 100,0 \\
\hline
\end{tabular}

Berdasarkan tabel 4.6 dapat dilihat bahwa dari 97 responden sebanyak 55 orang $(56,7 \%)$ memiliki peran kader yang kurang baik.

\section{Analisis Bivariat}

\section{a. Hubungan Tingkat Pengetahuan dengan Kunjungan Balita ke Posyandu}

\begin{tabular}{|c|c|c|c|c|c|c|}
\hline \multirow{2}{*}{$\begin{array}{c}\text { Tingkat } \\
\text { Pengetahuan }\end{array}$} & \multicolumn{4}{|c|}{ Kunjungan } & \multicolumn{2}{|c|}{ Total } \\
\cline { 2 - 7 } & Kurang & \multicolumn{2}{|c|}{ Baik } & \multicolumn{2}{|c|}{} \\
\cline { 2 - 7 } & $\mathbf{f}$ & $\mathbf{\%}$ & $\mathbf{f}$ & $\mathbf{\%}$ & $\mathbf{f}$ & \% \\
\hline Rendah & 45 & 84,9 & 8 & 15,1 & 53 & 100,0 \\
\hline Tinggi & 6 & 13,6 & 38 & 86,4 & 44 & 100,0 \\
\hline Jumlah & 51 & 52,6 & 46 & 47,4 & 97 & 100,0 \\
\hline P value $=\mathbf{0 , 0 0 0}$
\end{tabular}

Berdasarkan tabel 4.7 dapat dilihat bahwa kurangnya proporsi kunjungan balita ke posyandu lebih banyak pada responden yang memiliki tingkat pengetahuan rendah $(84,9 \%)$ dibandingkan dengan responden yang memiliki tingkat pengetahuan yang tinggi $(13,6 \%)$.

Hasil analisis uji statistik (chi-square) didapatkan nilai $\mathrm{p}=0,000(\mathrm{p}<0,05)$ berarti terdapat hubungan yang bermakna antara tingkat pengetahuan dengan kunjungan balita ke Posyandu di Wilayah Kerja Puskesmas

Anak Air Kota Padang tahun 2017. Sedangkan nilai OR didapatkan 35,625 yang berarti tingkat pengetahuan yang rendah memiliki peluang 35 kali tidak membawah anaknya berkunjuk ke posyandu balita.

\section{b. Hubungan Pekerjaan Ibu Balita dengan Kunjungan Balita ke Posyandu}

\begin{tabular}{|c|c|c|c|c|c|c|}
\hline \multirow{3}{*}{ Pekerjaan } & \multicolumn{4}{|c|}{ Kunjungan } & \multicolumn{2}{c|}{ Total } \\
\cline { 2 - 6 } & \multicolumn{2}{|c|}{ Kurang } & \multicolumn{2}{|c|}{ Baik } & \multicolumn{2}{c|}{} \\
\cline { 2 - 6 } & f & \% & f & \% & f & \% \\
\hline Bekerja & 39 & 86,7 & 6 & 13,3 & 45 & 100,0 \\
\hline Tidak & 12 & 23,1 & 40 & 76,9 & 52 & 100,0 \\
Bekerja & & & & & & \\
\hline Jumlah & 51 & 52,6 & 46 & 47,4 & 97 & 100,0 \\
\hline
\end{tabular}

$\mathbf{P}$ value $=0,000$

Berdasarkan tabel 4.8 dapat dilihat bahwa kurangnya proporsi kunjungan balita ke posyandu lebih banyak pada responden yang bekerja $(86,7 \%)$ dibandingkan dengan responden yang tidak bekerja $(23,1 \%)$.

Hasil analisis uji statistik (chi-square) didapatkan nilai $\mathrm{p}=0,000(\mathrm{p}<0,05)$ berarti terdapat hubungan yang bermakna antara pekerjaan dengan kunjungan balita ke Posyandu di Wilayah Kerja Puskesmas Anak Air Kota Padang tahun 2017. Sedangkan nilai OR didapatkan 21,667 yang berarti responden yang bekerja memiliki peluang 21 kali tidak membawa anaknya ke posyandu balita.

\section{c. Hubungan Peran Kader dengan Kunjungan Balita ke Posyandu}

\begin{tabular}{|c|c|c|c|c|c|c|}
\hline \multirow{2}{*}{$\begin{array}{c}\text { Peran } \\
\text { Kader }\end{array}$} & \multicolumn{4}{|c|}{ Kunjungan } & \multicolumn{2}{|c|}{ Total } \\
\cline { 2 - 7 } & Kurang & \multicolumn{2}{|c|}{ Baik } & \multicolumn{2}{c|}{} \\
\cline { 2 - 7 } & f & $\%$ & f & \% & f & $\%$ \\
\hline $\begin{array}{c}\text { Kurang } \\
\text { Baik }\end{array}$ & 46 & 83,6 & 9 & 16,4 & 55 & 100,0 \\
\hline
\end{tabular}




\begin{tabular}{|c|c|c|c|c|c|c|} 
Baik & 5 & 11,9 & 37 & 88,1 & 42 & 100,0 \\
\hline Jumlah & 51 & 52,6 & 46 & 47,4 & 97 & 100,0 \\
\hline
\end{tabular}

P value $=0,000$

Berdasarkan tabel 4.9 dapat dilihat bahwa kurangnya proporsi kunjungan balita ke posyandu lebih banyak pada peran kader yang kurang baik $(83,6 \%)$ dibandingkan dengan peran kader yang baik $(11,9 \%)$.

Hasil analisis uji statistik (chi-square) didapatkan nilai $\mathrm{p}=0,000(\mathrm{p}<0,05)$ berarti terdapat hubungan yang bermakna antara peran kader dengan kunjungan balita ke Posyandu di Wilayah Kerja Puskesmas Anak Air Kota Padang tahun 2017. Sedangkan nilai OR didapatkan 37,822 yang berarti responden yang bekerja memiliki peluang 37 kali tidak membawa anaknya ke posyandu balita.

\section{Analisis Univariat}

\section{Pembahasan}

\section{a. Kunjungan Ibu Balita ke Posyandu}

Berdasarkan hasil penelitian didapatkan bahwa dari 97 responden sebanyak 51 orang $(52,6 \%)$ memiliki kunjungan ke posyandu yang kurang. Hasil penelitian ini sebanding dengan penelitian sebelumnya yang dilakukan oleh Tuti Pradianto tentang kunjungan Ibu Balita ke posyandu di Kecamatan Botumoito tahun 2015, dari hasil penelitiannya menemukan $54 \%$ responden tidak melakukan kunjungan ke posyandu.

Pos pelayanan terpadu atau posyandu merupakan salah satu bentuk Upaya Kesehatan Bersumber Daya Masyarakat (UKBM) yang diselenggarakan dari, oleh, untuk dan bersama masyarakat dalam penyelenggaraan pembangunan kesehatan, guna memberdayakan masyarakat dan memberikan kemudahan kepada masyarakat dalam memperoleh pelayanan kesehatan dasar untuk mempercepat penurunan angka kematian ibu dan bayi. 12

Keberhasilan posyandu juga dapat tergambar dari tingkat kunjungan ibu dalam kegiatan posyandu yaitu ibu-ibu yang datang membawa balitanya ke posyandu setiap bulan untuk dilakukan penimbangan minimal 8 kali dalam setahun.

Menurut asumsi peneliti bahwa masih banyaknya ibu balita yang tidak membawa anaknya datang berkunjung ke posyandu, dimana ibu yang paling banyak tidak berkunjung adalah ibu yang memiliki tingkat pendidikan SMP dan berumur kurang dari 25 tahun, hal ini menunjukkan bahwa umur ibu yang masih relatif muda dimana biasanya ibuibu yang masih muda masih merasa enggan dan merasa malu untuk datang berkunjung membawa anaknya ke posyandu balita. Untuk itu perlu upaya untuk mengubah persepsi ibu yang masih muda untuk mau datang berkunjung ke posyandu balita yaitu dengan cara memberikan penyuluhan tentang pentingnya membawa anak balita ke posyandu

\section{b. Tingkat Pengetahuan}

Berdasarkan hasil penelitian didapatkan bahwa dari 97 responden sebanyak 53 orang $(54,6 \%)$ memiliki tingkat pengetahuan yang rendah tentang posyandu.

Hasil penelitian ini sebanding dengan penelitian sebelumnya yang dilakukan oleh Pipit Festy Wilianarti, dkk (2016) tentang tingkat pengetahuan ibu balita tentang posyandu di Wilayah Kerja Puskesmas Banjaroya, Kalibawang, Kulon Progo, menemukan bahwa $58 \%$ responden memiliki tingkat pengetahuan yang rendah tentang posyandu.

Pengetahuan adalah merupakan hasil dari "tahu" dan ini terjadi setelah orang melakukan pengindraan terhadap suatu objek tertentu. Pengindraan terjadi melalui pancaindra manusia, yakni : indra penglihatan, pendengaran, penciuman, rasa, dan raba. Sebagian besar pengetahuan manusia diperoleh melalui mata dan telinga. 13

Menurut asumsi peneliti bahwa masih banyaknya tingkat pengetahuan ibu balita yang rendah, hal ini dapat dilihat dari kuesioner penelitian didapatkan paling banyak ibu balita yang tidak dapat menjawab pertanyaan yang diajukan diantaranya

Untuk itu upaya yang dilakukan untuk meningkatkan pengetahuan ibu tentang posyandu adalah dengan cara meningkatkan promosi kesehatan berupa penyuluhan

kesehatan secara kontiniu dengan menggunakan media yang menarik seperti menggunakan leaflet yang bergambar menarik dengan bahasa yang dimengerti oleh ibu sehingga timbul rasa ingin tahu dan selanjutnya mau melakukan membawa anaknya datang ke posyandu. 


\section{c. Pekerjaan}

Berdasarkan hasil penelitian didapatkan bahwa dari 97 responden sebanyak 52 orang $(53,6 \%)$ tidak bekerja. Hasil penelitian ini sebanding dengan penelitian sebelumnya yang dilakukan oleh Tuti Pradianto, tentang pekerjaan Ibu Balita di Kecamatan Botumoito tahun 2015, dari hasil penelitiannya menemukan $65 \%$ responden tidak bekerja.

Ibu bekerja adalah ibu yang melakukan suatu kegiatan dengan tujuan

mencari nafkah dan mengharuskan meninggalkan rumah lebih dari 5 jam dalam sehari. Selain itu salah satu motif ibu bekerja adalah untuk aktualisasi diri guna menerapkan ilmu yang telah dimiliki olehnya. ${ }^{14}$

Menurut Pandji Anoraga, 1998 (dalam Khalimah (2007), kerja merupakan sesuatu yang dibutuhkan oleh manusia. Kebutuhan itu bisa bermacam-macam, berkembang dan berubah, bahkan seringkali tidak disadari oleh pelakunya. Seseorang bekerja karena ada sesuatu yang hendak dicapainya dan orang berharap bahwa aktivitas kerja yang dilakukannya akan membawanya kepada sesuatu keadaan yang lebih memuaskan dari pada keadaan sebelumnya.

Menurut asumsi peneliti bahwa terdapat sebagian kecil ibu balita yang

memiliki status pekerjaan, hal ini kemungkinan disebabkan sebagian ibu balita yang bekerja memiliki alasan ingin membantu menopang perekonomian keluarga dan ibu yang bekerja kebanyakan meninggalkan rumah lebih dari 5 jam serta jarak tempat bekerja juga cukup jauh sehingga tidak memungkinkan ibu untuk datang ke posyandu. Untuk itu upaya yang dilakukan bagi ibu yang bekerja agar tetap anaknya dibawah berkunjung ke posyandu adalah dengan cara menggantikan ibu dengan anggota keluarga yang lain untuk membawah anak ke posyandu.

\section{d. Peran Kader}

Berdasarkan hasil penelitian didapatkan bahwa dari 97 responden sebanyak 55 orang $(56,7 \%)$ memiliki peran kader yang kurang baik. Hasil penelitian ini sebanding dengan penelitian sebelumnya yang dilakukan Windasari, tentang peran kader dalam kegiatan posyandu di Kecamatan XIII Koto Kampar tahun 2014, menemukan bahwa $60 \%$ responden memiliki persepsi kurang baik terhadap peran kader.

Kader kesehatan adalah tenaga yang berasal dari masyarakat yang dipilih oleh masyarakat dan bekerja bersama untuk masyarakat secara sukarela. Kader kesehatan masyarakat adalah laki-laki atau wanita yang dipilih oleh masyarakat dan dilatih untuk menanggani masalah-masalah kesehatan perseorangan maupun masyarakat serta untuk bekerja dalam hubungan yang amat dekat dengan tempat- tempat pemberian pelayanan kesehatan. ${ }^{16}$

Menurut asumsi peneliti bahwa masih banyaknya kader yang tidak berperan dengan baik sebelum, selama kegiatan maupun sesudah kegiatan posyandu dilakukan, hal ini kemungkinan disebabkan karena masih kurang uang insentif yang diterima kader sehingga kebanyakan kader tidak aktif dalam kegiatan posyandu, selain itu dapat juga disebabkan karena faktor pendidikan kader yang masih rendah, kurangnya pelatihan yang didapatkan kader sehingga kontribusi kader terhadap kegiatan posyandu menjadi kurang 
2. Analisis Bivariat

\section{a. Hubungan Tingkat Pengetahuan dengan Kunjungan Ibu Balita ke Posyandu}

Berdasarkan hasil penelitian didapatkan bahwa kurangnya proporsi kunjungan balita ke posyandu lebih banyak pada responden yang memiliki tingkat pengetahuan rendah $(84,9 \%)$ dibandingkan dengan responden yang memiliki tingkat pengetahuan yang tinggi $(13,6 \%)$. Hasil analisis uji statistik (chi-square) didapatkan nilai $\mathrm{p}=0,000(\mathrm{p}<0,05)$ berarti terdapat hubungan yang bermakna antara tingkat pengetahuan dengan kunjungan balita ke Posyandu di Wilayah Kerja Puskesmas Anak Air Kota Padang tahun 2017. Sedangkan nilai OR didapatkan 35,625 yang berarti tingkat pengetahuan yang rendah memiliki peluang 35 kali tidak membawah anaknya berkunjuk ke posyandu balita.

Hasil ini penelitian ini sebanding dengan penelitian sebelumnya yang dilakukan Pipit Festy Wilianarti, dkk (2016) tentang faktor-faktor yang mempengaruhi kunjungan ke posyandu di Wilayah Kerja Puskesmas Banjaroya, Kalibawang, Kulon Progo, menemukan bahwa dari hasil penelitian mengenai faktor pengetahuan berhubungan dengan kunjungan ke posyandu $(\mathrm{p}=0,026)$.

Hasil penelitian ini sejalan dengan teori Notoatmodjo yang menyatakan bahwa pengetahuan merupakan domain yang sangat penting untuk terbentuknya tindakan seseorang. Berdasarkan pengalaman dan penelitian ternyata perilaku yang didsari oleh pengetahuan akan lebih langgeng daripada perilaku yang tidak didasari oleh pengetahuan. ${ }^{13}$

Pada penelitian ini menunjukkan bahwa tingkat pengetahuan ibu balita tidak sepenuhnya dapat mempengaruhi kunjungan ke posyandu balita. Hal ini terbukti dari hasil penelitian ini didapatkan 8 orang ibu yang memiliki tingkat pengetahuan rendah dapat melakukan kunjungan ke posyandu balita. Hal ini kemungkinan disebabkan karena ibu balita banyak yang tidak bekerja sehingga memiliki banyak waktu untuk datang ke posyandu balita. Selain itu didapatkan juga sebanyak 6 orang ibu yang memiliki tingkat pengetahuan tinggi namun kunjungan ke posyandu balita masih kurang. Hal ini kemungkinan disebabkan oleh ibu tidak mengetahui jadwal kegiatan posyandu dalam hal ini peran kader masih kurang.

Untuk itu upaya yang dilakukan untuk meningkatkan pengetahuan ibu tentang posyandu adalah dengan cara meningkatkan promosi kesehatan berupa penyuluhan

kesehatan secara kontiniu dengan menggunakan media yang menarik seperti menggunakan leaflet yang bergambar menarik dengan bahasa yang dimengerti oleh ibu sehingga timbul rasa ingin tahu dan selanjutnya mau melakukan membawa anaknya datang ke posyandu.

\section{b. Hubungan Pekerjaan Ibu Balita dengan Kunjungan Ibu Balita ke Posyandu}

Berdasarkan hasil penelitian didapatkan bahwa kurangnya proporsi kunjungan balita ke posyandu lebih banyak pada responden yang bekerja $(86,7 \%)$ dibandingkan dengan responden yang tidak bekerja $(23,1 \%)$. Hasil analisis uji statistik (chi-square) didapatkan nilai $\mathrm{p}=0,000$ $(\mathrm{p}<0,05)$ berarti terdapat hubungan yang bermakna antara pekerjaan dengan kunjungan balita ke Posyandu di Wilayah Kerja Puskesmas Anak Air Kota Padang tahun 2017. Sedangkan nilai OR didapatkan 21,667 yang berarti responden yang bekerja memiliki peluang 21 kali tidak membawa anaknya ke posyandu balita.

Hasil ini penelitian ini sebanding dengan penelitian sebelumnya yang dilakukan oleh Tuti Pradianto, tentang faktor-faktor yang mempengaruhi ketidakhadiran Ibu Balita dan Penggunaan Posyandu di

Kecamatan Botumoito tahun 2015, menyatakan bahwa perilaku kunjungan ibu balita di posyandu dapat dipengaruhi oleh 
beberapa faktor antara lain pekerjaan ibu $(\mathrm{p}=$ 0,007).

Penelitian ini berbeda dengan penelitian sebelumnya yang dilakukan oleh Elva Pristiani tahun 2015 tentang hubungan status pekerjaan ibu balita dengan kunungan ibu balita ke posyandu di wilayah kerja Puskesmas Pamandati Kabupaten Konawe Selatan, dari hasil penelitiannya menemukan tidak ada hubungan status pekerjaan ibu dengan kunungan ibu balita ke posyandu. Metode pada penelitian yang dilakukan oleh Elva Pristiani adalah observasi sedangkan pada penelitian menggunakan metode survey. Dilihat dari jumlah sampel penelitian ini lebih banyak dibandingkan penelitian sebelumnya serta cara pengambilannya pun berbeda.

Perilaku ibu membawa balita ke posyandu bagi ibu yang bekerja dan tidak bekerja seharusnya tidak memiliki perbedaan, dikarenakan perilaku tersebut didasari oleh seberapa besar pengetahuan ibu tentang posyandu dan bagaimana menyikapinya. Namun rendahnya jumlah kunjungan balita ke posyandu menunjukkan bahwa ada pengaruh yang disebabkan oleh faktor status ibu bekerja atau tidak. Kepercayaan dan perilaku kesehatan ibu juga hal yang penting, karena penggunaan sarana kesehatan oleh anak berkaitan erat dengan perilaku dan kepercayaan ibu tentang kesehatan dan mempengaruhi keaktifan ke posyandu. ${ }^{13}$

Pekerjaan berhubungan dengan pendidikan dan pendapatan serta berperan penting dalam kehidupan sosial ekonomi dan memiliki keterkaitan dengan faktor lain seperti kesehatan. Hal ini sesuai dengan penelitian Khomsan (2007) bahwa pekerjaan termasuk dalam salah satu sumber pendapatan dalam keluarga. Dengan adanya pekerjaan tetap dalam suatu keluarga, maka keluarga tersebut relative terjamin pendapatannya setiap bulan. Jika keluarga tidak memiliki pekerjaan tetap, maka pendapatan keluarga setiap bulannya juga tidak dapat dipastikan. 15

Seseorang yang mempunyai pekerjaan dengan waktu yang cukup padat akan

mempengaruhi ketidakhadiran dalam pelaksanaan posyandu. Pada umumnya orang tua tidak mempunyai waktu luang, sehingga semakin tinggi aktivitas pekerjaan orang tua semakin sulit datang ke posyandu. Hal ini sesuai dengan penelitian Sambas (2002) yang menyatakan bahwa ibu balita yang tidak bekerja berpeluang baik untuk berkunjung ke posyandu dibandingkan dengan ibu yang bekerja. Hasil penelitian yang dilakukan oleh Widiastuty (2006) juga ditemukan bahwa ibu yang bekerja menyebabkan tidak membawa anaknya ke posyandu untuk di timbang.

Pada penelitian ini menunjukkan adanya hubungan yang bermakna antara pekerjaan dengan kunjungan ke posyandu balita. Walaupun demikian pekerjaan ibu balita tidak sepenuhnya mempengaruhi kunjungan ke posyandu. Hal ini terbukti dari hasil penelitian ini dimana terdapat 6 orang ibu yang bekerja masih dapat melakukan kunjungan ke posyandu balita. Hal ini kemungkinan disebabkan karena pekerjaan yang dilakukan ibu tidak sepenuhnya menghabiskan waktu untuk bekejera seharian sehingga ibu balita masih bisa memiliki kesempatan untuk datang ke posyandu balita. Selain itu didapatkan juga sebanyak 12 orang ibu yang tidak bekerja tetapi kunjungan ke posyandu balita juga masih kurang. Hal ini kemungkinan disebabkan oleh kesibukan ibu dirumah dalam mengurus rumah tangga sehingga tidak memiliki waktu datang berkunjung ke posyandu. Untuk itu upaya yang dilakukan bagi ibu yang bekerja agar tetap anaknya dibawah berkunjung ke posyandu adalah dengan cara menggantikan ibu dengan anggota keluarga yang lain untuk membawah anak ke posyandu

\section{c. Hubungan Peran Kader dengan Kunjungan Ibu Balita ke Posyandu}

Berdasarkan hasil penelitian didapatkan bahwa kurangnya proporsi kunjungan balita ke posyandu lebih banyak pada peran kader yang kurang baik $(83,6 \%)$ dibandingkan dengan peran kader yang baik $(11,9 \%)$. Hasil analisis uji statistik (chisquare) didapatkan nilai $\mathrm{p}=0,000(\mathrm{p}<0,05)$ berarti terdapat hubungan yang bermakna antara peran kader dengan kunjungan balita ke Posyandu di Wilayah Kerja Puskesmas

Anak Air Kota Padang tahun 2017. Sedangkan nilai OR didapatkan 37,822 yang berarti responden yang bekerja memiliki peluang 37 kali tidak membawa anaknya ke posyandu balita.. 
Hasil ini penelitian ini sebanding dengan penelitian sebelumnya yang dilakukan penelitian Windasari, tentang faktor-faktor yang mempengaruhi kunjungan ibu balita ke posyandu di Kecamatan XIII Koto Kampar tahun 2014, menyatakan bahwa perilaku kunjungan ibu balita di posyandu dapat dipengaruhi oleh beberapa faktor antara lain peran $\operatorname{kader}(\mathrm{p}=0,014)$.

Kader sebagai warga masyarakat setempat yang dipilih dan ditinjau oleh masyarakat dan dapat bekerja secara sukarela. Kader secara sukarela bersedia berperan melaksanakan dan mengelola kegiatan

posyandu. Kader merupakan tenaga masyarakat yang dianggap paling dekat dengan masyarakat dan diharapkan mereka dapat melakukan pekerjaannya secara sukarela tanpa menuntut imbalan berupa uang atau materi lainnya. Namun ada juga kader kesehatan yang disediakan sebuah rumah atau sebuah kamar serta beberapa peralatan secukupnya oleh masyarakat setempat. ${ }^{17}$

Pada penelitian ini menunjukkan adanya hubungan yang bermakna antara pekerjaan dengan kunjungan ke posyandu balita. Walaupun demikian peran kader bukan merupakan satu-satunya yang dapat mempengaruhi ibu melakukan kunjungan ke posyandu balita. Hal ini terbukti dari hasil penelitian ini dimana terdapat 9 orang ibu dengan peran kader kurang namun ibu balita masih ada yang dapat melakukan kunjungan ke posyandu balita. Hal ini kemungkinan disebabkan karena faktor lain selain peran kader diantaranya adanya dukungan sosial dalam hal ini adanya dukungan keluarga dalam mendampingi ibu untuk melakukan kunjungan ke posyandu balita. Selain itu didapatkan juga sebanyak 5 orang ibu dengan peran kader yang baik namun kunjungan ke posyandu balita masih kurang. Hal ini kemungkinan disebabkan oleh kesibukan ibu dirumah dalam mengurus rumah tangga sehingga tidak memiliki waktu datang berkunjung ke posyandu walaupun sudah diberitahu oleh kader untuk datang berkunjung ke posyandu.

\section{KESIMPULAN DAN SARAN}

\section{A. Kesimpulan}

1. Lebih dari separoh responden memiliki kunjungan ke posyandu yang kurang di Wilayah Kerja Puskesmas Anak Air Kota Padang tahun 2017.

2. Lebih dari separoh responden memiliki tingkat pengetahuan yang rendah tentang posyandu di Wilayah Kerja Puskesmas Anak Air Kota Padang tahun 2017.

3. Lebih dari separoh responden tidak bekerja di Wilayah Kerja Puskesmas Anak Air Kota Padang tahun 2017.

4. Lebih dari separoh responden memiliki peran kader yang kurang baik di Wilayah Kerja Puskesmas Anak Air Kota Padang tahun 2017.

5. Terdapat hubungan yang bermakna antara tingkat pengetahuan dengan kunjungan balita ke Posyandu di Wilayah Kerja Puskesmas Anak Air Kota Padang tahun 2017.

6. Terdapat hubungan yang bermakna antara pekerjaan dengan kunjungan balita ke Posyandu di Wilayah Kerja Puskesmas Anak Air Kota Padang tahun 2017.

7. Terdapat hubungan yang bermakna antara peran kader dengan kunjungan balita ke Posyandu di Wilayah Kerja Puskesmas Anak Air Kota Padang tahun 2017.

\section{B. Saran}

1. Bagi Puskesmas

Harapan peneliti bagi puskesmas melalui petugas kesehatan agar dapat meningkatkan promosi kesehatan berupa penyuluhan kesehatan secara kontiniu dengan menggunakan media yang menarik seperti menggunakan leaflet yang bergambar menarik dengan bahasa yang dimengerti oleh ibu sehingga timbul rasa ingin tahu dan selanjutnya mau melakukan membawa anaknya datang ke posyandu.

2. Bagi Dinas Kesehatan

Harapan peneliti bagi Dinas Kesehatan Kabupaten/Kota agar dapat 
melaksanakan pelatihan bagi petugas kesehatan di setiap puskesmas khususnya Puskesmas Anak Air, sehingga petugas kesehatan memiliki kemampuan untuk memberikan penyuluhan/konseling kepada ibu balita tentang pentingya posyandu.

3. Bagi Peneliti Selanjutnya Harapan peneliti bagi peneliti selanjutnya agar melihat metode dan desain yang berbeda serta faktorfaktor lain yang berhubungan dengan dengan kunjungan ibu balita ke posyandu seperti tingkat pendidikan dan peran tokoh masyarakat.

\section{DAFTAR PUSTAKA}

1. Kemenkes RI, 2012. Ayo ke Posyandu Setiap Bulan, Posyandu Menjaga Anak dan Ibu Tetap Sehat. Jakarta.

2. Depkes RI, 2011. Kinerja dua Tahun Kementrian Kesehatan Republik Indonesia. Jakarta.

3. Kemenkes RI, 2013. Promosi Kesehatan, Depkes, Jakarta

4. Depkes RI, 2006. Pedoman Umum Pengelolaan Posyandu, Depkes RI, Jakarta

5. Depkes RI, 2008. Pedoman Pemberian Makanan Pendamping ASI, Depkes RI, Jakarta.

6. Kemenkes RI, 2014. Tumbuh Kembang Balita, Depkes RI, Jakarta

7. Depkes RI, 2004. Pedoman Teknis Pembinaan Kader UPGK. Jakarta;

8. Riskesdas, 2013. Riset Kesehatan Dasar. Jakarta

9. Dinkes Sumbar, 2015. Profil Kesehatan Sumatera Barat. Padang.

10. Dinkes Kota Padang, 2016. Profil Kesehatan Kota Padang. Padang
11. Kemenkes RI, 2015. Revitalisasi Posyandu. Jakarta.

12. Kemenkes RI, 2011. Menuju Masyarakat Sehat yang Mandiri dan Berkeadilan. Jakarta.

13. Notoatmodjo, 2011. Kesehatan Masyarakat Ilmu dan Seni. Jakarta : Rineka Cipta.

14. Tuti Pradianto, 2015. Faktor-faktor yang mempengaruhi ketidak hadiran Ibu Balita dan Penggunaan Posyandu di Kecamatan Botumoito. Jurnal Penelitian

15. Anisa Sujarwati, 2013. Peran Perempuan dalam Perekonomian Rumah Tangga di Dusun Pantog Kulon, Banjaroya, Kalibawang, Kulon Progo. Yogyakarta.

16. Anisa, dkk, 2016. Pedoman Pelaksanaan Posyandu Bagi Tenaga Kesehatan, Mahasiswa Kesehatan, dan Kader Posyandu. Yogyakarta : Nuha Medika.

17. Dinkes Sumbar, 2013. Gerakan Peduli Posyandu Provinsi Sumatera Barat tahun 2013. Padang

18. Notoatmodjo, 2012. Metodologi Penelitian Kesehatan. Jakarta : Rineka Cipta. 